\title{
The effect of folate fortification on folic acid-based homocysteine- lowering intervention and stroke risk: a meta-analysis
}

\author{
Rui Zeng ${ }^{1}$, Chun-Hua Xu ${ }^{2}$, Yuan-Ning Xu ${ }^{1}$, Ya-Li Wang ${ }^{1}$ and Mian Wang ${ }^{1, *}$ \\ 'Department of Cardiovascular Diseases, West China Hospital, School of Clinical Medicine, Sichuan University, \\ Chengdu 610041, People's Republic of China: ${ }^{2}$ Department of Cardiovascular Diseases, The Second People's \\ Hospital of Neijiang, Neijiang, People's Republic of China
}

Submitted 14 April 2014: Final revision received 14 August 2014: Accepted 25 August 2014: First published online 17 0ctober 2014

\begin{abstract}
Objective: Folate and vitamin $\mathrm{B}_{12}$ are two vital regulators in the metabolic process of homocysteine, which is a risk factor of atherothrombotic events. Low folate intake or low plasma folate concentration is associated with increased stroke risk. Previous randomized controlled trials presented discordant findings in the effect of folic acid supplementation-based homocysteine lowering on stroke risk. The aim of the present review was to perform a meta-analysis of relevant randomized controlled trials to check the how different folate fortification status might affect the effects of folic acid supplementation in lowering homocysteine and reducing stroke risk.

Design: Relevant randomized controlled trials were identified through formal literature search. Homocysteine reduction was compared in subgroups stratified by folate fortification status. Relative risks with $95 \%$ confidence intervals were used as a measure to assess the association between folic acid supplementation and stroke risk.

Setting: The meta-analysis included fourteen randomized controlled trials,

Subjects: A total of 39420 patients.

Results: Homocysteine reductions were 26.99 (SD 1.91) \%, 18.38 (SD 3.82) \% and 21.30 (SD 1.98) \%, respectively, in the subgroups without folate fortification, with folate fortification and with partial folate fortification. Significant difference was observed between the subgroups with folate fortification and without folate fortification $(P=0.05)$. The relative risk of stroke was 0.88 (95\% CI $0.77,1.00$, $P=0.05)$ in the subgroup without folate fortification, 0.94 (95\% CI $0.58,1.54$, $P=0.82)$ in the subgroup with folate fortification and 0.91 (95\% CI 0.82, 1.01, $P=0 \cdot 09)$ in the subgroup with partial folate fortification.

Conclusions: Folic acid supplementation might have a modest benefit on stroke prevention in regions without folate fortification.
\end{abstract}

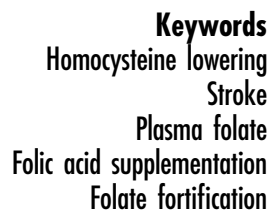

Hyperhomocysteinaemia, a condition characterized as marked elevation of plasma homocysteine, is closely related to atherosclerosis ${ }^{(1)}$. Previous studies have observed that a high level of homocysteine is associated with enhanced inflammatory processes, increased oxidative stress and a series of atherothrombotic events ${ }^{(2-4)}$. Therefore, total homocysteine-lowering therapy seems to be a possible practice to reduce the incidence of these outcomes ${ }^{(5)}$. Folate and vitamin $\mathrm{B}_{12}$ are two vital regulators in the metabolic process of homocysteine. Folic acid supplementation might reduce serum homocysteine concentration ${ }^{(6,7)}$. Holmes et al. suggested that increasing folate levels with folic acid supplementation might alleviate the effect of methylenetetrahydrofolate reductase $M T H F R \quad 677 \mathrm{C} \rightarrow \mathrm{T}$ variant on homocysteine concentration ${ }^{(8)}$. One prospective cohort study showed that a reduction of $25 \%(3 \mu \mathrm{mol} / \mathrm{l})$ in serum homocysteine lowered the risk of stroke by $24 \%$ and the risk of CHD by $18 \%$ in $7 \cdot 3$ years of follow-up ${ }^{(9)}$. However, low folate intake or low plasma folate concentration is associated with increased stroke risk ${ }^{(10)}$. In actual practice, the effect of folic acid supplementation to reduce serum homocysteine might be affected by the folate status of a population.

Some randomized controlled trials (RCT) have been performed to investigate folic acid intervention and the 
associated cardiovascular and cerebrovascular risks. Although several meta-analyses pooled the results of the RCT, they did not reach consensus ${ }^{(11-13)}$. Significant variance in study characteristics, such as baseline homocysteine level of the participants and whether folate fortification was implemented, were the major sources of heterogeneity. Considering the proved effect of folate fortification on plasma homocysteine control $^{(8)}$, the present meta-analysis aimed to study the potential effect of folate fortification on folic acid-based homocysteine-lowering intervention and stroke risk by stratifying previous RCT according to fortification status.

\section{Method}

\section{Search strategy}

The basic framework of the meta-analysis followed the PRISMA (Preferred Reporting Items for Systematic Reviews and Meta-Analyses) statement recommended by the Cochrane Collaboration ${ }^{(14)}$. Relevant studies published between 1 January 1980 and 1 March 2014 were searched in PubMed, Web of Science, Cochrane Library, EMBASE and ClinicalTrials.gov. Introductions and reference lists of previous meta-analyses and reviews were manually searched to avoid possible missing of qualifying trials. Only studies published in English were retrieved since the screening criteria have strict inclusion requisites for reporting of patient baseline and intervention details. The following search strategy and terms were used to identify possible RCT: ('folate' OR 'folic acid' (All Fields)) AND ('homocysteine' (All Fields)) AND ('stroke' OR 'cardiovascular disease' OR 'cerebrovascular attack' OR 'brain hemorrhage' OR 'intracranial hemorrhage' OR 'heart attack' OR 'angina' OR 'myocardial ischemia' OR 'myocardial infarct' (All Fields)) AND ('randomized controlled trial' OR 'RCT') (All Fields)). Two authors performed the whole search process and assessed the eligibility of the RCT independently. Discrepant judgements were resolved through group discussion.

\section{Inclusion criteria and data extraction}

Screening criteria had the following strict inclusion requisites: (i) randomized controlled trial (RCT); (ii) patients were divided into an active treatment group with folic acid supplementation (with or without vitamins $\mathrm{B}_{6}$ and $\mathrm{B}_{12}$ ) $v$. a placebo or very-low-dose control group; (iii) folate fortification status of the region where the trial was conducted had to be reported in the study or in relevant studies; (iv) the number of stroke cases had to be reported separately in the active treatment and control groups; (v) the study involved no less than 200 participants; and (vi) follow-up $\geq 6$ months. Two authors extracted original data independently and a third author cross-checked the data. Inconsistencies and discrepancies were resolved by discussion based on reviewing of the original reports.
The key data extracted included year of publication, number of patients involved, patients' baseline folate level/characteristics at study entry, active treatment, length of follow-up, geographical location of the study and results of efficacy and safety outcomes (homocysteine reduction and stroke occurrence).

\section{Statistical analysis}

According to the folate fortification status of the trials, studies involved in the present meta-analysis were stratified into subgroups with folate fortification, without folate fortification and with partial folate fortification, respectively. In these three subgroups, the effect of folic acid intervention on homocysteine reduction and stroke risk were compared. Statistical analysis followed the Cochrane Handbook for Systematic Reviews of Interventions Version 5.1.0 (www.cochrane.org) for meta-analysis. To compare the level of homocysteine lowering in the three subgroups, original data on the baseline homocysteine level and median decrease of homocysteine at the end of follow-up were extracted. The level of decrease in each of the three subgroups was calculated as a percentage. The $t$ test for two samples assuming equal variance was performed to check whether there was a significant difference in homocysteine lowering between any two of the three subgroups. Review Manager 5.2 software (Cochrane Collaboration, Oxford, UK) was used for calculation and comparison of treatment effects. Relative risks (RR) with $95 \%$ confidence intervals were calculated for head-to-head comparisons of the association between folic acid supplementation and risk of stroke. A two-tailed $P$ value $\leq 0.05$ was used to denote statistical significance. The heterogeneity between different trials was assessed by $\chi^{2}$ tests and the $I^{2}$ statistic. $I^{2}$ values of $25 \%, 50 \%$ and $75 \%$ suggest low, moderate and high degree of heterogeneity, respectively ${ }^{(15)}$. $P<0 \cdot 1$ in $\chi^{2}$ tests suggests significant heterogeneity. Primary assessment of heterogeneity was conducted based on a fixed-effects model with Mantel-Haenszel methods. $P \geq 0 \cdot 1$ and $I^{2} \leq 50 \%$ mean the trials have no significant heterogeneity and a fixed-effects model was used, while $P<0 \cdot 1$ and $I^{2}>50 \%$ suggest the trials have significant heterogeneity ${ }^{(15)}$. Then, the source of heterogeneity was further analysed. If there was no significant clinical or method heterogeneity, a random-effects model was applied to make estimates. Otherwise, descriptive analysis was performed. Results obtained from both fixed-effects and random-effects models were compared to examine the influence of smallstudy effects on results due to the possible between-study heterogeneity ${ }^{(15)}$. Where necessary, sensitivity analyses were performed to test the stability of identified outcomes.

\section{Results}

The systematic search found twenty-two articles for detailed assessment. Among them, seven were excluded 


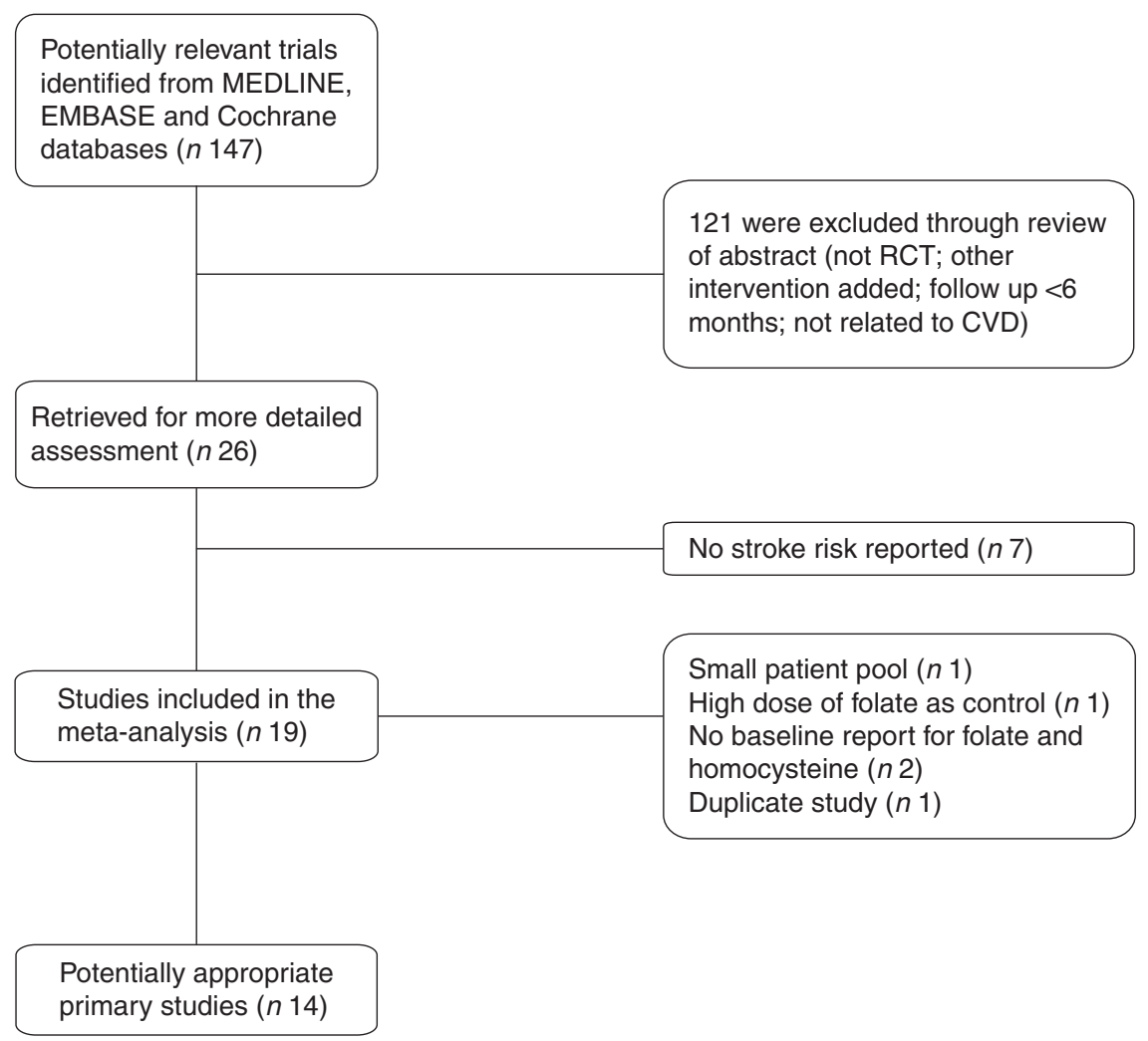

Fig. 1 Flowchart of the search process (RCT, randomized controlled trial)

since no stroke risk was reported ${ }^{(16-22)}$, one was excluded due to small patient pool ${ }^{(23)}$, three were excluded due to no baseline report for folate and homocysteine ${ }^{(22,24,25)}$, one was excluded due to high dose of folate $(1 \mathrm{mg} / \mathrm{d})$ as control ${ }^{(26)}$ and one was excluded due to duplicate study $^{(27)}$. The final fourteen RCT enrolled 39420 patients. Among them, seven were included in the without folate fortification subgroup ${ }^{(28-34)}$, four were included in the with folate fortification subgroup ${ }^{(35-38)}$ and three were included in the partial folate fortification subgroup ${ }^{(39-41)}$. The screening process of potential articles is summarized in a flowchart (Fig. 1). The key characteristics of the fourteen RCT enrolled are presented in Table 1. The baseline folate levels of the participants and their changes in homocysteine during the whole intervention in the trials are summarized in Table 2.

Homocysteine reductions in the three subgroups were calculated and are presented in Fig. 2. Homocysteine reductions were 26.99 (SD 1.91) \%, 18.38 (SD 3.82) \% and 21.30 (SD 1.98 ) \%, respectively, in the subgroups without folate fortification, with folate fortification and with partial folate fortification (Fig. 2). Significant difference was observed between the subgroups with folate fortification and without folate fortification $(P=0.05)$, but no significant difference was observed between the subgroups with folate fortification and partial folate fortification $(P=0.63)$ or between the subgroups with partial folate fortification and without folate fortification $(P=0 \cdot 14$; Fig. 2$)$.
Figures 3 and 4 show the pooled RR of stroke in the three subgroups. Heterogeneity test showed no significant heterogeneity in the without folate fortification subgroup $\left(P=0.42, I^{2}=1 \%\right)$ and the partial folate fortification subgroup $\left(P=0 \cdot 15, I^{2}=47 \%\right.$; Fig. 3$)$, but found significant heterogeneity in the subgroup with folate fortification $\left(P=0.05, I^{2}=61 \%\right.$; Fig. 4). Thus, a fixed-effects model was applied to make estimates in the former two subgroups and a random-effects model was used in the subgroup with folate fortification. The RR of stroke was 0.88 (95\% CI $0.77,1.00, P=0.05)$ in the subgroup without folate fortification, 0.91 (95\% CI 0.82, 1.01, $P=0.09$ ) in the subgroup with partial folate fortification (Fig. 3) and 0.94 (95\% CI $0.58,1.54, P=0.82$ ) in the subgroup with folate fortification (Fig. 4). Sensitivity analysis found that exclusion of any single study from the analysis did not alter the overall findings for folic acid supplementation on stroke risk. The estimate from the fixed-effects model was similar to the estimate from the random-effects model, suggesting that a small-study effect on the overall intervention effect estimate was not significant.

\section{Discussion}

The present meta-analysis included fourteen RCT with a total of 39420 patients to study the effect of folic acid supplementation on stroke risk by stratifying trials 
Table 1 Key characteristics of the trials included in the present meta-analysis

\begin{tabular}{|c|c|c|c|c|c|c|c|c|c|c|}
\hline Study & $\begin{array}{l}\text { Duration of } \\
\text { study }\end{array}$ & $\begin{array}{l}\text { Characteristics of } \\
\text { participants at study } \\
\text { entry }\end{array}$ & $\begin{array}{l}\text { No. of } \\
\text { patients }\end{array}$ & Blinding & Active treatment & Control & Stroke & $\begin{array}{l}\text { Maximum } \\
\text { follow-up } \\
\text { (months) }\end{array}$ & $\begin{array}{l}\text { Geographical } \\
\text { location }\end{array}$ & $\begin{array}{l}\text { Folate } \\
\text { fortification }\end{array}$ \\
\hline Mark et al. ${ }^{(28)}$ & $1985-1991$ & $\begin{array}{l}\text { Oesophageal } \\
\text { dysplasia }\end{array}$ & 3318 & Double & $\begin{array}{l}\text { Folic acid } 0.8 \mathrm{mg} / \mathrm{d} \text {, } \\
\text { vitamins } B_{6} \text { and } B_{12}\end{array}$ & Placebo & Fatal stroke & 72 & China & No \\
\hline Toole et al. ${ }^{(39)}$ & 1996-2003 & Ischaemic stroke & 3680 & Double & $\begin{array}{l}\text { Folic acid } 2.5 \mathrm{mg} / \mathrm{d} \\
\text { vitamins } B_{6} \text { and } B_{12}\end{array}$ & $\begin{array}{l}\text { Folic acid } 20 \mu \mathrm{g} / \mathrm{d} \\
\text { and vitamins } B_{6} \\
\text { and } B_{12}\end{array}$ & $\begin{array}{l}\text { Recurrent ischaemic } \\
\text { stroke (fatal \& } \\
\text { non-fatal) }\end{array}$ & 24 & $\begin{array}{l}\text { Canada, USA, } \\
\text { Scotland }\end{array}$ & Partial \\
\hline Liem et al. ${ }^{(29)}$ & 1998-2003 & $\mathrm{CHD}$ & 593 & None & $\begin{array}{l}\text { Folic acid } 0.5 \mathrm{mg} / \mathrm{d} \text { and } \\
\text { standard care }\end{array}$ & Standard care & $\begin{array}{l}\text { Fatal and non-fatal } \\
\text { stroke and TIA }\end{array}$ & 24 & Netherlands & No \\
\hline Bonaa et al. ${ }^{(30)}$ & 1998-2002 & MI & 3749 & Double & $\begin{array}{l}\text { Folic acid } 0.8 \mathrm{mg} / \mathrm{d} \text { and } \\
\text { vitamin } B_{12} \text { with or } \\
\text { without } B_{6}\end{array}$ & Placebo & $\begin{array}{l}\text { Any fatal and non-fatal } \\
\text { stroke (including } \\
\text { SAH) }\end{array}$ & 36 & Norway & No \\
\hline Lonn et al. ${ }^{(40)}$ & 2000-2005 & $\begin{array}{l}\text { Vascular disease and } \\
\text { risk factors for } \\
\text { atherosclerosis }\end{array}$ & 5522 & Double & $\begin{array}{l}\text { Folic acid } 2.5 \mathrm{mg} / \mathrm{d} \\
\text { vitamins } \mathrm{B}_{6} \text { and } \mathrm{B}_{12}\end{array}$ & Placebo & $\begin{array}{l}\text { Fatal and non-fatal } \\
\text { stroke }\end{array}$ & 60 & $\begin{array}{l}\text { Canada, USA, } \\
\text { Brazil, Western } \\
\text { Europe, Slovakia }\end{array}$ & Partial \\
\hline Zoungas et al. ${ }^{(35)}$ & 1998-2003 & CKD & 315 & Double & Folic acid $15 \mathrm{mg} / \mathrm{d}$ & Placebo & $\begin{array}{l}\text { Fatal and non-fatal } \\
\text { stroke }\end{array}$ & 43 & $\begin{array}{l}\text { Australia and New } \\
\text { Zealand }\end{array}$ & Yes \\
\hline Jamison et al. ${ }^{(36)}$ & 2001-2003 & CKD & 2056 & Double & $\begin{array}{l}\text { Folic acid } 40 \mathrm{mg} / \mathrm{d} \text {, } \\
\text { vitamins } \mathrm{B}_{6} \text { and } \mathrm{B}_{12}\end{array}$ & Placebo & $\begin{array}{l}\text { Fatal and non-fatal } \\
\text { thromboembolic } \\
\text { stroke }\end{array}$ & 38 & USA & Yes \\
\hline Albert et al. ${ }^{(37)}$ & 1998-2005 & $\begin{array}{l}\text { CVD or } 3 \text { risk factors } \\
\text { for CVD }\end{array}$ & 5442 & Double & $\begin{array}{l}\text { Folic acid } 2.5 \mathrm{mg} / \mathrm{d} \\
\text { vitamins } B_{6} \text { and } B_{12}\end{array}$ & Placebo & $\begin{array}{l}\text { Fatal and non-fatal } \\
\text { stroke (ischaemic, } \\
\text { haemorrhagic) }\end{array}$ & 87 & USA & Yes \\
\hline Ebbing et al. ${ }^{(31)}$ & 1999-2006 & $\begin{array}{l}\text { Stable angina, ACS } \\
\text { or aortic valve } \\
\text { stenosis }\end{array}$ & 2319 & Double & $\begin{array}{l}\text { Folic acid } 0.8 \mathrm{mg} / \mathrm{d} \text { and } \\
\text { vitamin } B_{12} \text { with or } \\
\text { without } B_{6}\end{array}$ & Placebo & $\begin{array}{l}\text { Non-fatal } \\
\text { thromboembolic } \\
\text { stroke and fatal } \\
\text { stroke }\end{array}$ & 38 & Norway & No \\
\hline House et al. ${ }^{(38)}$ & $2001-2007$ & $\begin{array}{l}\text { Type } 1 \text { or } 2 \text { diabetes } \\
\text { and diabetic } \\
\text { nephropathy }\end{array}$ & 238 & Double & $\begin{array}{l}\text { Folic acid } 2.5 \mathrm{mg} / \mathrm{d} \text { and } \\
\text { vitamins } B_{6} \text { and } B_{12}\end{array}$ & Placebo & $\begin{array}{l}\text { Fatal and non-fatal } \\
\text { stroke and TIA }\end{array}$ & 32 & Canada & Yes \\
\hline Heinz et al. ${ }^{(32)}$ & 2002-2008 & ESRD & 650 & Double & $\begin{array}{l}\text { Folic acid } 5 \mathrm{mg} / \mathrm{d} \text { and } \\
\text { vitamins } B_{6} \text { and } B_{12}\end{array}$ & $\begin{array}{l}\text { Folic acid } 0.2 \mathrm{mg} / \mathrm{d} \text {, } \\
\text { vitamins } B_{12} \\
\text { and } B_{6}\end{array}$ & $\begin{array}{l}\text { Fatal and non-fatal } \\
\text { stroke }\end{array}$ & 72 & $\begin{array}{l}\text { North and east } \\
\text { Germany }\end{array}$ & No \\
\hline Galan et al. ${ }^{(33)}$ & 2003-2009 & CVD & 3374 & Double & $\begin{array}{l}\text { Folic acid } 0.56 \mathrm{mg} / \mathrm{d} \text { and } \\
\text { vitamins } B_{6} \text { and } B_{12}\end{array}$ & Placebo & $\begin{array}{l}\text { Fatal and non-fatal } \\
\text { stroke }\end{array}$ & 58 & France & No \\
\hline $\begin{array}{l}\text { SEARCH } \\
\text { Collaborative } \\
\text { Group }{ }^{(34)}\end{array}$ & 1998-2005 & MI & 12064 & Double & $\begin{array}{l}\text { Folic acid } 2 \mathrm{mg} / \mathrm{d} \text { and } \\
\text { vitamin } \mathrm{B}_{12}\end{array}$ & Placebo & $\begin{array}{l}\text { Any fatal and non-fatal } \\
\text { stroke (including } \\
\text { SAH) }\end{array}$ & 78 & UK & No \\
\hline $\begin{array}{l}\text { VITATOPS Trial } \\
\text { Study Group }{ }^{(41)}\end{array}$ & 1998-2009 & Stroke or TIA & 8164 & Double & $\begin{array}{l}\text { Folic acid } 2 \mathrm{mg} / \mathrm{d} \text {, } \\
\text { vitamins } \mathrm{B}_{12} \text { and } \mathrm{B}_{6}\end{array}$ & Placebo & $\begin{array}{l}\text { Fatal and non-fatal } \\
\text { stroke }\end{array}$ & 24 & 20 countries in sum & Partial \\
\hline
\end{tabular}

SEARCH, Study of the Effectiveness of Additional Reductions in Cholesterol and Homocysteine; VITATOPS, VITAmins TO Prevent Stroke; MI, myocardial infarction; CKD, chronic kidney disease; ACS, acute coronary syndrome; ESRD, end-stage renal disease; TIA, transient ischaemic attack; SAH, subarachnoid haemorrhage. 
Table 2 Homocysteine change during intervention

\begin{tabular}{|c|c|c|c|c|c|}
\hline Study & $\begin{array}{l}\text { Median baseline } \\
\text { folate concentration } \\
(\mathrm{nmol} / \mathrm{l})\end{array}$ & $\begin{array}{c}\text { Baseline } \\
\text { homocysteine } \\
\text { concentration } \\
(\mu \mathrm{mol} / \mathrm{l})\end{array}$ & $\begin{array}{l}\text { Median } \\
\text { homocysteine } \\
\text { reduction at the end } \\
\text { of follow-up }(\mu \mathrm{mol} / \mathrm{l})\end{array}$ & $\begin{array}{l}\text { Percentage median } \\
\text { homocysteine } \\
\text { reduction compared } \\
\text { with baseline }\end{array}$ & $\begin{array}{l}\text { Folate } \\
\text { fortification }\end{array}$ \\
\hline Mark et al. ${ }^{(28)}$ & NA & NA & NA & NA & No \\
\hline Toole et al. ${ }^{(39)}$ & >20 (plasma) & $13 \cdot 4$ & $2 \cdot 3$ & $17 \cdot 2$ & Partial \\
\hline Liem et al. ${ }^{(29)}$ & 17 (plasma) & $12 \cdot 0$ & $2 \cdot 6$ & $21 \cdot 7$ & No \\
\hline Bonaa et al. ${ }^{(30)}$ & $13 \cdot 1$ (plasma) & $13 \cdot 1$ & 3.6 & $27 \cdot 5$ & No \\
\hline Lonn et al. ${ }^{(40)}$ & $27 \cdot 6$ (plasma) & $12 \cdot 2$ & 2.4 & $19 \cdot 7$ & Partial \\
\hline Zoungas et al. ${ }^{(35)}$ & 1354 (erythrocyte) & $27 \cdot 0$ & $3 \cdot 1$ & $11 \cdot 5$ & Yes \\
\hline Jamison et al. ${ }^{(36)}$ & 19 (plasma) & 21.5 & $6 \cdot 2$ & $28 \cdot 8$ & Yes \\
\hline Albert et al. ${ }^{(37)}$ & 8.9 (plasma) & $12 \cdot 1$ & $2 \cdot 3$ & $19 \cdot 0$ & Yes \\
\hline Ebbing et al. ${ }^{(31)}$ & 〜10-15 (plasma) & $10 \cdot 8$ & $3 \cdot 2$ & $29 \cdot 6$ & No \\
\hline House et al. ${ }^{(38)}$ & 36.16 (plasma) & $15 \cdot 5$ & $2 \cdot 2$ & $14 \cdot 2$ & Yes \\
\hline Heinz et al. ${ }^{(32)}$ & $12 \cdot 7$ (plasma) & $30 \cdot 0$ & $10 \cdot 4$ & $34 \cdot 7$ & No \\
\hline Galan et al. ${ }^{(33)}$ & $6 \cdot 7$ (plasma) & 12.9 & $3 \cdot 1$ & $24 \cdot 0$ & No \\
\hline SEARCH Collaborative Group ${ }^{(34)}$ & 7.4 (plasma) & $13 \cdot 5$ & $3 \cdot 3$ & 24.4 & No \\
\hline VITATOPS Trial Study Group ${ }^{(41)}$ & 962 (erythrocyte) & 14.4 & 3.9 & $27 \cdot 1$ & Partial \\
\hline
\end{tabular}

NA, not available.

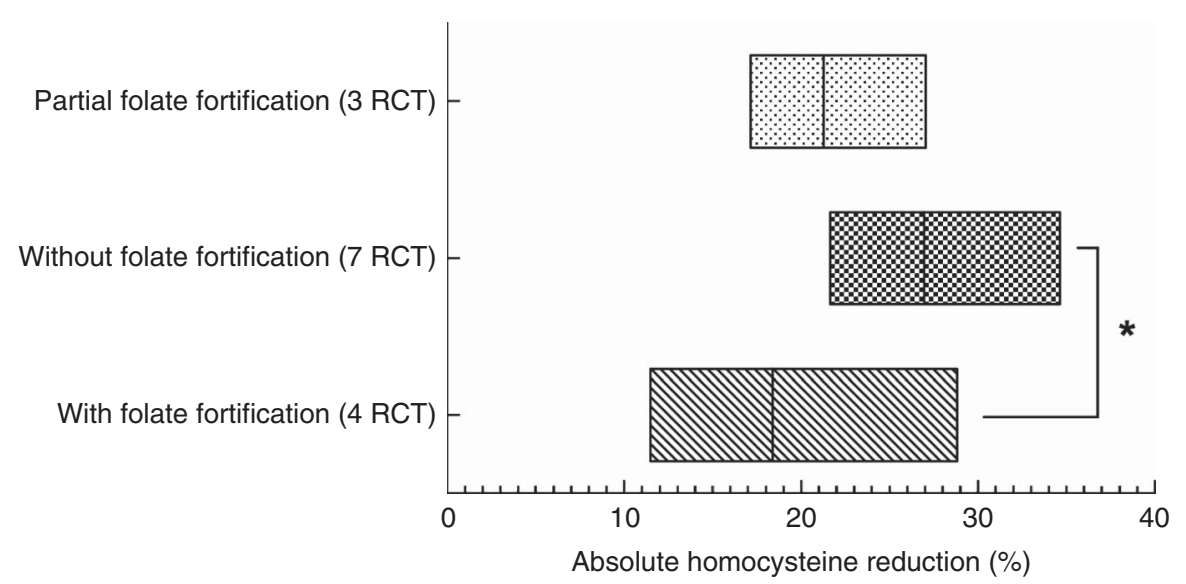

Fig. 2 The level of homocysteine reduction at the end of follow-up among fourteen randomized controlled trials (RCT), with a total of 39420 patients, studying the effect of folic acid supplementation on stroke risk, with trials stratified according to the status of folate fortification. The absolute mean homocysteine reduction in the active treatment group in the three different folate fortification subgroups is shown; the floating bars depict minimum to maximum, with a line at the mean. Significant difference: ${ }^{*} \leq 0.05$

according to the status of folate fortification. It was found that homocysteine reduction was significantly higher in the regions without folate fortification than in the regions with fortification. In addition, folic acid supplementation could significantly reduce the risk of stroke in the regions without folate fortification. Although mild benefit was observed in the subgroup with partial folate fortification, it did not reach a statistically significant level. The main difference between the present compared with previous meta-analyses is the stratification of trials according to the status of folate fortification.

Homocysteine is a risk factor of cerebral small-vessel disease ${ }^{(42-44)}$. In the present study, the significantly higher homocysteine lowering observed in the subgroup without folate fortification was associated with a significantly lowered risk of stroke events. It is possible that the benefits of homocysteine lowering might be related to the reduced cerebral small-vessel diseases contributing to both ischaemic and haemorrhagic stroke. Shirodaria et al.'s physiological study found that low-dose folic acid supplementation $(0.4 \mathrm{mg} / \mathrm{d})$ was sufficient to improve vascular endothelial function and no additional benefit was achieved through increasing the dose to $5 \mathrm{mg} / \mathrm{d}^{(45)}$. After folate fortification in the USA and Canada, stroke mortality decreased slightly ${ }^{(46)}$. This helps to explain why lower stroke risk due to folic acid supplementation was observed in the subgroup without folate fortification but not in the subgroup with folate fortification in the present study. Previous studies reported that through inhibiting hepatic synthesis of apo A1, a major HDL apolipoprotein, homocysteine could reduce serum concentration of HDL cholesterol $^{(47)}$. Therefore, homocysteine-induced apo A1 synthesis inhibition is a possible mechanism of atherosclerosis development ${ }^{(48,49)}$. Low serum concentration of HDL cholesterol has been considered a predictive factor of stroke and a target for treatment ${ }^{(50)}$. However, the trials 


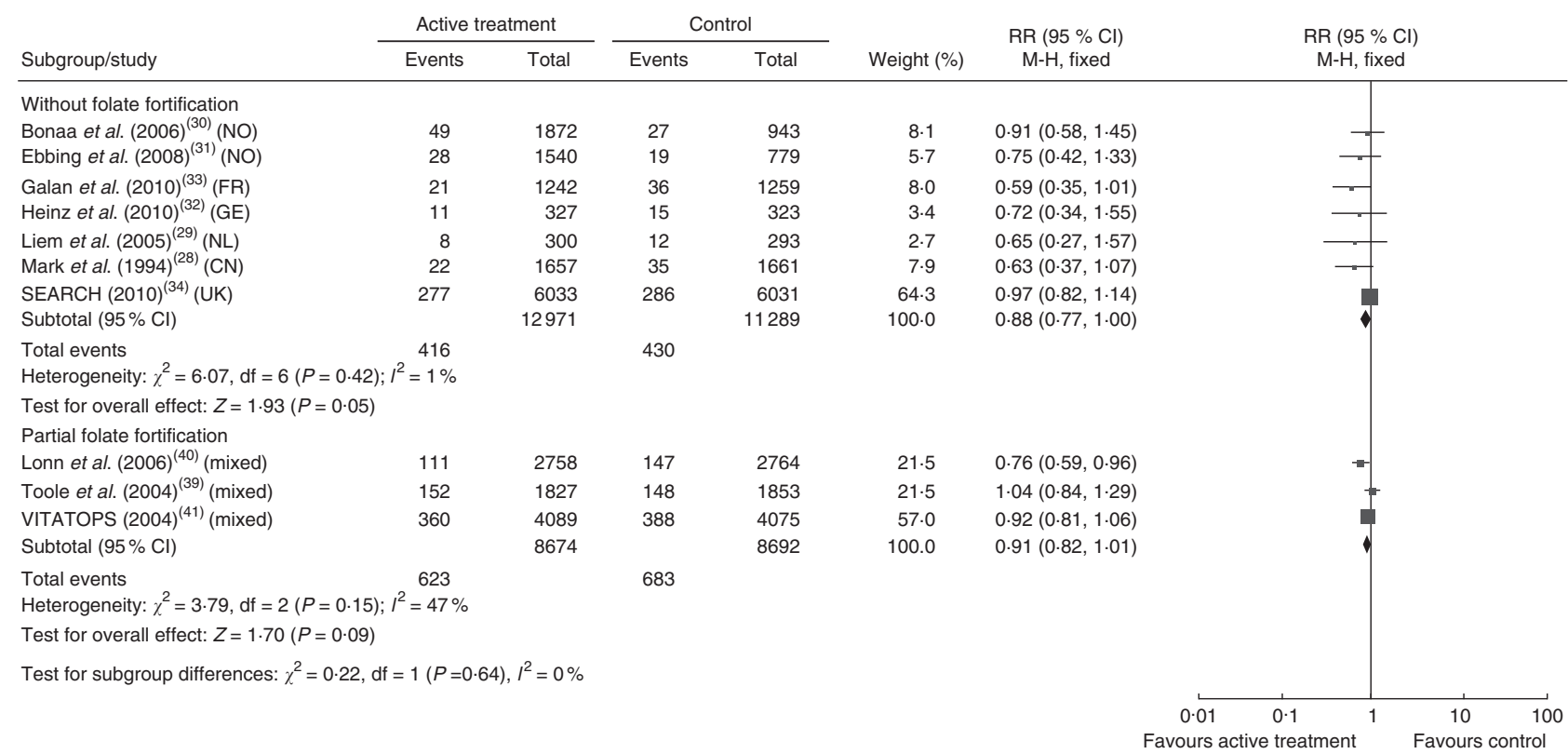

Fig. 3 Pooled relative risk (RR) of stroke in the subgroups without folate fortification and with partial folate fortification. The studyspecific RR and $95 \% \mathrm{Cl}$ are represented by the black square and horizontal line, respectively; the area of the black square is proportional to the specific-study weight to the overall meta-analysis. The centre of the black diamond presents the pooled RR risk and its width represents the pooled $95 \% \mathrm{Cl}$ (NO, Norway; FR, France; GE, Germany; NL, Netherlands; CN, China)

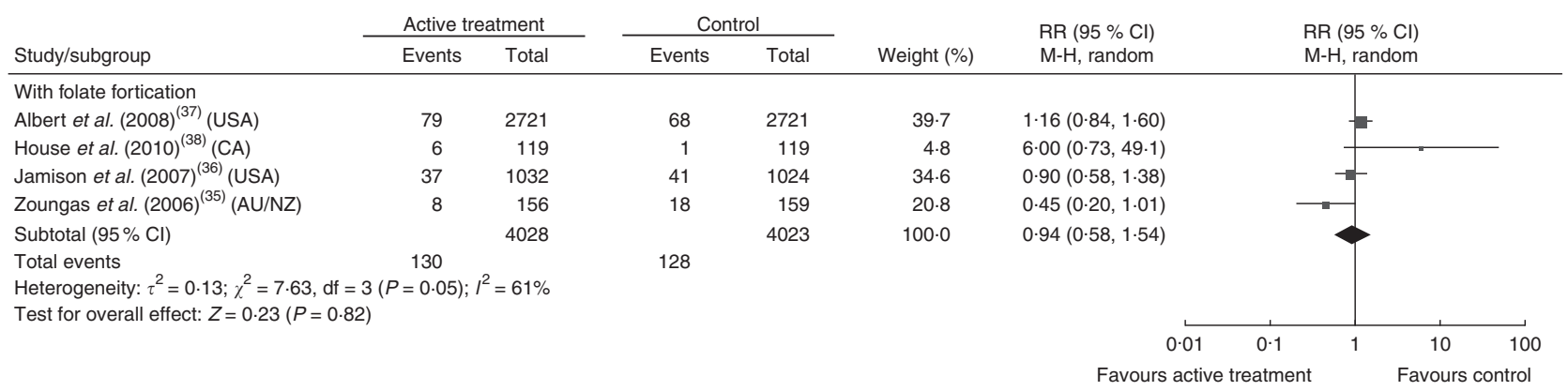

Fig. 4 Pooled relative risk (RR) of stroke in the subgroup with folate fortification. The study-specific $\mathrm{RR}$ and $95 \% \mathrm{Cl}$ are represented by the black square and horizontal line, respectively; the area of the black square is proportional to the specific-study weight to the overall meta-analysis. The centre of the black diamond presents the pooled RR risk and its width represents the pooled $95 \% \mathrm{Cl}$ (CA, Canada; AU/NZ, Australia/New Zealand)

involved in the present meta-analysis all recruited patients with high cardiovascular risk. It is highly possible they had already received intensive lipid profile interventions before folic acid supplementation. Therefore, the effect of homocysteine lowering on HDL cholesterol was difficult to demonstrate in these trials. However, for populations with middle to high risk of cerebrovascular events and without proper medication for lowering lipids, the effect of folate might be more evident. Holmes et al. ${ }^{(8)}$ observed that in regions with increasing levels of folate or with established policies of population folate fortification, the effect of folic acid-based homocysteine-lowering interventions was not evident in reducing genetic variance-associated stroke risk. The present study also implies the possible benefit is more achievable in the regions without folate fortification.
Some recent studies have suggested that homocysteine is not a primary regulator of endothelial function. Lieb et al. studied the pathophysiological processes of arterial stiffness, which might contribute to atherosclerosis. They observed that homocysteine level was not related to any surrogate biomarkers for arterial stiffness ${ }^{(51)}$. Menon et al. studied hyperhomocystinaemia in patients with moderate chronic kidney disease and also found it was not a risk factor for all-cause or cardiovascular mortality after adjustment for kidney function ${ }^{(52)}$. In fact, homocysteine's role in disease development might be more evident at early stage than at later stages. Hodis et al. ${ }^{(16)}$ observed that B-vitamin supplementation could significantly reduce carotid artery intima media thickness and thus lower the progression of early-stage subclinical atherosclerosis. 
However, this effect was not observed during progression of aortic or coronary artery calcification, which indicates late-stage atherosclerosis. This finding suggests that homocysteine lowering might be effective at early stages of vascular disease. Serum/plasma or erythrocyte concentrations of folate provide an accurate picture of a population's folate status. According to WHO, the cut-off for defining folate deficiencies based on metabolic indicators are: $<10 \mathrm{nmol} / 1(4.4 \mathrm{ng} / \mathrm{ml})$ for serum folate or $<305 \mathrm{nmol} / 1 \quad(140 \mathrm{ng} / \mathrm{ml})$ for erythrocyte folate ${ }^{(53)}$. Based on findings of the present study, it is recommended that for patients with high stroke risk (such as patients with chronic vascular disease, diabetes and/or high blood cholesterol or TAG) in folate-deficient regions, folic acid supplementation could be considered.

The major limitation of the present study is the variance of the trials in respect to patient baseline characteristics, intensity of treatment, duration, primary/secondary end points and other design features. For example, the total baseline serum homocysteine level varied from $11 \mu \mathrm{mol} / 1$ to over $30 \mu \mathrm{mol} / 1$ in the fourteen trials involved. Since previous prospective studies indicated that patients with homocysteine above $10 \cdot 2 \mu \mathrm{mol} / 1$ carried doubled risk of stroke and $20 \mu \mathrm{mol} / 1$ was associated with ninefold higher stroke risk ${ }^{(54,55)}$, it is reasonable that homocysteinelowering interventions might achieve a better stroke preventive effect in patients with high homocysteine. This might lead to selection bias in the present study. However, sensitivity testing confirmed the robustness of the findings.

\section{Conclusion}

To sum up, the present meta-analysis found a significant benefit of folic acid supplementation in reducing stroke risk in regions without folate fortification. Homocysteine lowering was also significantly higher in these regions compared with the regions with fortification. Since folic acid supplementation is a proven safe, inexpensive and easy-to-manipulate intervention, it could be recommended to patients with high risk of stroke in regions without folate fortification.

\section{Acknowledgements}

Financial support: This study was supported by the National Natural Science Foundation of China (grant number 81200153) and the Science Foundation of Health Department, Sichuan Province (grant number 120213). The funders had no role in the design, analysis or writing of this article. Conflict of interest: None. Authorship: R.Z. and C.-H.X. contributed equally to the study. R.Z. carried out research design, data collection, data analysis, manuscript preparation and manuscript revision. C.-H.X. carried out data collection and data analysis. Y.-N.X. carried out research design and manuscript revision. Y.-L.W. carried out data analysis and manuscript preparation. M.W. carried out research design and applying for grants. Ethics of human subject participation: Ethical approval was not required.

\section{References}

1. Guthikonda S \& Haynes WG (2006) Homocysteine: role and implications in atherosclerosis. Curr Atheroscler Rep $\mathbf{8}$, 100-106.

2. Ridker PM, Manson JE, Buring JE et al. (1999) Homocysteine and risk of cardiovascular disease among postmenopausal women. JAMA 281, 1817-1821.

3. Lawson MF (1998) Homocysteine and atherothrombosis. $N$ Engl J Med 339, 477-478; author reply 479.

4. Curro M, Condello S, Caccamo D et al. (2009) Homocysteineinduced toxicity increases TG2 expression in Neuro2a cells. Amino Acids 36, 725-730.

5. Yap S, Rushe H, Howard PM et al. (2001) The intellectual abilities of early-treated individuals with pyridoxinenonresponsive homocystinuria due to cystathionine $\beta$-synthase deficiency. J Inherit Metab Dis 24, 437-447.

6. Chiuve SE, Giovannucci EL, Hankinson SE et al. (2005) Alcohol intake and methylenetetrahydrofolate reductase polymorphism modify the relation of folate intake to plasma homocysteine. Am J Clin Nutr 82, 155-162.

7. de Bree A, Verschuren WM, Bjorke-Monsen AL et al. (2003) Effect of the methylenetetrahydrofolate reductase $677 \mathrm{C} \rightarrow \mathrm{T}$ mutation on the relations among folate intake and plasma folate and homocysteine concentrations in a general population sample. Am J Clin Nutr 77, 687-693.

8. Holmes MV, Newcombe P, Hubacek JA et al. (2011) Effect modification by population dietary folate on the association between MTHFR genotype, homocysteine, and stroke risk: a meta-analysis of genetic studies and randomised trials. Lancet 378, 584-594.

9. Homocysteine Studies Collaboration (2002) Homocysteine and risk of ischemic heart disease and stroke: a metaanalysis. JAMA 288, 2015-2022.

10. He K, Merchant A, Rimm EB et al. (2004) Folate, vitamin $B_{6}$, and $B_{12}$ intakes in relation to risk of stroke among men. Stroke 35, 169-174.

11. Bazzano LA, Reynolds K, Holder KN et al. (2006) Effect of folic acid supplementation on risk of cardiovascular diseases: a meta-analysis of randomized controlled trials. JAMA 296, 2720-2726.

12. Wang X, Qin X, Demirtas H et al. (2007) Efficacy of folic acid supplementation in stroke prevention: a meta-analysis. Lancet 369, 1876-1882.

13. Huo Y, Qin X, Wang J et al. (2012) Efficacy of folic acid supplementation in stroke prevention: new insight from a meta-analysis. Int J Clin Pract 66, 544-551.

14. Liberati A, Altman DG, Tetzlaff J et al. (2009) The PRISMA statement for reporting systematic reviews and metaanalyses of studies that evaluate health care interventions: explanation and elaboration. J Clin Epidemiol 62, e1-e34.

15. Higgins JP, Thompson SG, Deeks JJ et al. (2003) Measuring inconsistency in meta-analyses. BMJ 327, 557-560.

16. Hodis HN, Mack WJ, Dustin L et al. (2009) High-dose B vitamin supplementation and progression of subclinical atherosclerosis: a randomized controlled trial. Stroke 40, 730-736.

17. Schnyder G, Roffi M, Flammer Y et al. (2002) Effect of homocysteine-lowering therapy with folic acid, vitamin $\mathrm{B}_{12}$, and vitamin $\mathrm{B}_{6}$ on clinical outcome after percutaneous coronary intervention: the Swiss Heart study: a randomized controlled trial. JAMA 288, 973-979. 
18. Righetti M, Ferrario GM, Milani S et al. (2003) Effects of folic acid treatment on homocysteine levels and vascular disease in hemodialysis patients. Med Sci Monit 9, PI19-Pl24.

19. Lange H, Suryapranata H, De Luca G et al. (2004) Folate therapy and in-stent restenosis after coronary stenting. $N$ Engl J Med 350, 2673-2681.

20. Vianna AC, Mocelin AJ, Matsuo T et al. (2007) Uremic hyperhomocysteinemia: a randomized trial of folate treatment for the prevention of cardiovascular events. Hemodial Int 11, 210-216.

21. Potena L, Grigioni F, Masetti M et al. (2008) Long-term effect of folic acid therapy in heart transplant recipients: follow-up analysis of a randomized study. Transplantation 85, 1146-1150.

22. de Jager CA, Oulhaj A, Jacoby R et al. (2012) Cognitive and clinical outcomes of homocysteine-lowering B-vitamin treatment in mild cognitive impairment: a randomized controlled trial. Int J Geriatr Psychiatry 27, 592-600.

23. Righetti M, Serbelloni P, Milani S et al. (2006) Homocysteinelowering vitamin B treatment decreases cardiovascular events in hemodialysis patients. Blood Purif 24, 379-386.

24. Liem AH, van Boven AJ, Veeger NJ et al. (2004) Efficacy of folic acid when added to statin therapy in patients with hypercholesterolemia following acute myocardial infarction: a randomised pilot trial. Int J Cardiol 93, 175-179.

25. Bostom AG, Carpenter MA, Kusek JW et al. (2011) Homocysteine-lowering and cardiovascular disease outcomes in kidney transplant recipients: primary results from the Folic Acid for Vascular Outcome Reduction in Transplantation trial. Circulation 123, 1763-1770.

26. Wrone EM, Hornberger JM, Zehnder JL et al. (2004) Randomized trial of folic acid for prevention of cardiovascular events in end-stage renal disease. J Am Soc Nephrol 15, 420-426.

27. Liem A, Reynierse-Buitenwerf GH, Zwinderman $\mathrm{AH}$ et al. (2003) Secondary prevention with folic acid: effects on clinical outcomes. J Am Coll Cardiol 41, 2105-2113.

28. Mark SD, Wang W, Fraumeni JF Jr et al. (1996) Lowered risks of hypertension and cerebrovascular disease after vitamin/mineral supplementation: the Linxian Nutrition Intervention Trial. Am J Epidemiol 143, 658-664.

29. Liem A, Reynierse-Buitenwerf GH, Zwinderman AH et al. (2005) Secondary prevention with folic acid: results of the Goes extension study. Heart 91, 1213-1214.

30. Bonaa KH, Njolstad I, Ueland PM et al. (2006) Homocysteine lowering and cardiovascular events after acute myocardial infarction. $N$ Engl J Med 354, 1578-1588.

31. Ebbing M, Bleie O, Ueland PM et al. (2008) Mortality and cardiovascular events in patients treated with homocysteinelowering $\mathrm{B}$ vitamins after coronary angiography: a randomized controlled trial. JAMA 300, 795-804.

32. Heinz J, Kropf S, Domrose U et al. (2010) B vitamins and the risk of total mortality and cardiovascular disease in endstage renal disease: results of a randomized controlled trial. Circulation 121, 1432-1438.

33. Galan P, Kesse-Guyot E, Czernichow S et al. (2010) Effects of $\mathrm{B}$ vitamins and omega 3 fatty acids on cardiovascular diseases: a randomised placebo controlled trial. BMJ 341, c6273.

34. Study of the Effectiveness of Additional Reductions in Cholesterol and Homocysteine (SEARCH) Collaborative Group; Armitage JM, Bowman L, Clarke RJ et al. (2010) Effects of homocysteine-lowering with folic acid plus vitamin $\mathrm{B}_{12}$ vs placebo on mortality and major morbidity in myocardial infarction survivors: a randomized trial. JAMA 303, 2486-2494.

35. Zoungas S, McGrath BP, Branley P et al. (2006) Cardiovascular morbidity and mortality in the Atherosclerosis and Folic Acid Supplementation Trial (ASFAST) in chronic renal failure: a multicenter, randomized, controlled trial. J Am Coll Cardiol 47, 1108-1116.
36. Jamison RL, Hartigan P, Kaufman JS et al. (2007) Effect of homocysteine lowering on mortality and vascular disease in advanced chronic kidney disease and end-stage renal disease: a randomized controlled trial. JAMA 298, 1163-1170.

37. Albert CM, Cook NR, Gaziano JM et al. (2008) Effect of folic acid and $\mathrm{B}$ vitamins on risk of cardiovascular events and total mortality among women at high risk for cardiovascular disease: a randomized trial. JAMA 299, 2027-2036.

38. House AA, Eliasziw M, Cattran DC et al. (2010) Effect of B-vitamin therapy on progression of diabetic nephropathy: a randomized controlled trial. JAMA 303, 1603-1609.

39. Toole JF, Malinow MR, Chambless LE et al. (2004) Lowering homocysteine in patients with ischemic stroke to prevent recurrent stroke, myocardial infarction, and death: the Vitamin Intervention for Stroke Prevention (VISP) randomized controlled trial. JAMA 291, 565-575.

40. Lonn E, Yusuf S, Arnold MJ et al. (2006) Homocysteine lowering with folic acid and B vitamins in vascular disease. N Engl J Med 354, 1567-1577.

41. VITATOPS Trial Study Group (2010) B vitamins in patients with recent transient ischaemic attack or stroke in the VITAmins TO Prevent Stroke (VITATOPS) trial: a randomised, double-blind, parallel, placebo-controlled trial. Lancet Neurol 9, 855-865.

42. Hassan A, Hunt BJ, O'Sullivan M et al. (2004) Homocysteine is a risk factor for cerebral small vessel disease, acting via endothelial dysfunction. Brain 127, 212-219.

43. Kloppenborg RP, Nederkoorn PJ, van der Graaf Y et al. (2011) Homocysteine and cerebral small vessel disease in patients with symptomatic atherosclerotic disease. The SMART-MR study. Atherosclerosis 216, 461-466.

44. Tseng YL, Chang YY, Liu JS et al. (2009) Association of plasma homocysteine concentration with cerebral white matter hyperintensity on magnetic resonance images in stroke patients. J Neurol Sci 284, 36-39.

45. Shirodaria C, Antoniades C, Lee J et al. (2007) Global improvement of vascular function and redox state with lowdose folic acid: implications for folate therapy in patients with coronary artery disease. Circulation 115, 2262-2270.

46. Yang Q, Botto LD, Erickson JD et al. (2006) Improvement in stroke mortality in Canada and the United States, 1990 to 2002. Circulation 113, 1335-1343.

47. Liao D, Tan H, Hui R et al. (2006) Hyperhomocysteinemia decreases circulating high-density lipoprotein by inhibiting apolipoprotein A-I protein synthesis and enhancing HDL cholesterol clearance. Circ Res 99, 598-606.

48. Choy PC, Mymin D, Zhu Q et al. (2000) Atherosclerosis risk factors: the possible role of homocysteine. Mol Cell Biochem 207, 143-148.

49. Ma K, Lv S, Liu B et al. (2013) CTLA4-IgG ameliorates homocysteine-accelerated atherosclerosis by inhibiting T-cell overactivation in apoE(-/-) mice. Cardiovasc Res 97, 349-359.

50. Sanossian N, Saver JL, Navab M et al. (2007) High-density lipoprotein cholesterol: an emerging target for stroke treatment. Stroke 38, 1104-1109.

51. Lieb W, Larson MG, Benjamin EJ et al. (2009) Multimarker approach to evaluate correlates of vascular stiffness: the Framingham Heart Study. Circulation 119, 37-43.

52. Menon V, Sarnak MJ, Greene T et al. (2006) Relationship between homocysteine and mortality in chronic kidney disease. Circulation 113, 1572-1577.

53. World Health Organization \& Food and Agriculture Organization of the Unted Nations (2006) Guidelines on Food Fortification with Micronutrients. Geneva: WHO.

54. von Eckardstein A \& Assmann G (1997) Plasma homocysteine levels and mortality in patients with coronary artery disease. N Engl J Med 337, 1632-1633.

55. Graham IM, Daly LE, Refsum HM et al. (1997) Plasma homocysteine as a risk factor for vascular disease. The European Concerted Action Project. JAMA 277, 1775-1781. 